\title{
MADRASAH
}

Jurnal Pendidikan dan Pembelajaran Dasar

p ISSN: 1979-5599 | e ISSN: 2502-194X

\section{Analisis Butir Soal IPA Try Out USBN Tahun Ajaran 2018/2019 dalam Kaitannya dengan Level Kognitif}

\author{
Nuril Huda1, Tutik Sri Wahyuni' ${ }^{2}$ \\ 1 Universitas Islam Negeri Maulana Malik Ibrahim Malang Indonesia, \\ 2Institut Agama Islam Negeri Tulungagung Indonesia \\ 1nurilhuda26@uin-malang.ac.id, 2tswahyuni@gmail.com
}

DOI: $10.18860 /$ mad.v12i1.7686

Abstract: This research aims to: 1) find out the characteristics of the science items try out National Standards School Exams (USBN) in the academic year 2018/2019 based on Classical Test Theory $(\mathrm{CTT}) ; 2)$ find out the number of the science items try out USBN in relation to cognitive level. This type of research is a descriptive research with a quantitative approach. The data obtained was a computer answer sheet of 5022 students who took USBN try out of Elementary School 2019 on February 21, 2019 in Tulungagung Regency. The results showed that: 1) The characteristics of the science items try out USBN in the academic year 2018/2019 based on Classical Test Theory (CTT) in aspects of: a) validity of 35 items valid; b) the reliability value of 0.818 is very high; c) the level of difficulty level: 4 items (11.43\%) are difficult, 9 items (25.71\%) are moderate, 16 items (45.71\%) are easy and 6 items $(7.14 \%)$ are very easy; d) discriminating power: 3 items $(8.57 \%)$ are bad, 12 items $(34.29 \%)$ are good enough, 15 items (42.86\%) are moderate, and 5 items $(14.29 \%)$ are good; e) the quality of options: 17 items $(48.57 \%)$ without revision, 9 items $(25.71 \%)$ one option revision, 5 items (14.29\%) of 2 option revisions, and 4 items (11.43\% ) wrong revision of 3 options; f) 13 items (37.14\%) about the science try out USBN have quite good and good characteristics, so they can be included in the question bank; 2) items the science of try out USBN in relationship with cognitive level, 11 items (31.43\%) category L1 (knowledge), 10 items (28.57\%) category L1 (understanding), 4 items (11.43\%) category L2 (application), and 10 items (28.57\%) category L3 (reasoning). The science try out USBN was dominated at the cognitive level L1.

Keywords. science items; USBN; Classical Test Theory (CTT); cognitive level

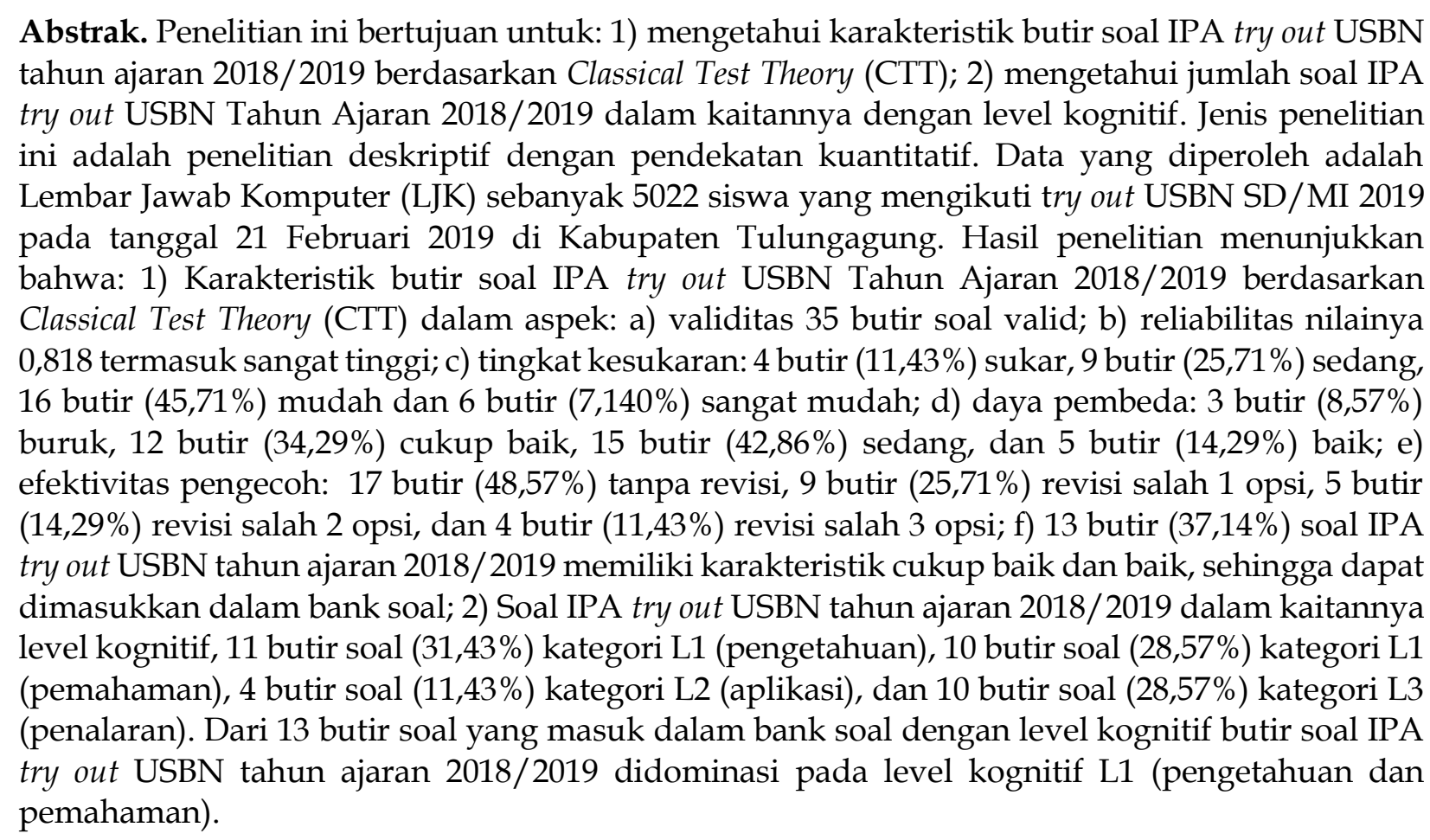

Kata Kunci. Soal IPA; USBN; classical test theory; level kognitif 
Received : 22-09-2019

Aproved : 24-12-2019

Reviesed : 15-10-2019

Published : 31-12-2019

Copyright (c) Madrasah Jurnal Pendidikan dan Pembelajaran Dasar. All Right Reserved.

This is an open access article under the CC BY-NC-ND license

(http://creativecommons.org/licenses/by-nc-nd/4.0/).

Correspondence Address: nurilhuda26@uin-malang.ac.id

\section{A. PENDAHULUAN}

Pendidikan memegang peranan penting bagi kemajuan suatu bangsa. Kualitas sumber daya manusia dapat ditingkatkan melalui pendidikan. Dalam hal ini, lembaga pendidikan seperti sekolah memegang peranan penting dalam meningkatkan prestasi siswa dan kualitas lulusannya. Prestasi belajar siswa dapat diketahui melalui kegiatan pengukuran. Pengukuran prestasi belajar merupakan kegiatan melakukan kuantifikasi gejala atau objek berupa prestasi yang dinyatakan dalam bentuk angka (Mardapi, 2012:7). Selanjutnya, hasil pengukuran tersebut diolah menjadi informasi yang digunakan dalam penentuan kebijakan. Dengan kata lain, kegiatan evaluasi hasil belajar memerlukan data yang diperoleh melalui kegiatan pengukuran.

Evaluasi merupakan bagian yang tidak dapat dipisahkan dari proses pembelajaran. Evaluasi bertujuan untuk mengukur pemahaman dan penguasaan konsep dari materi yang telah dipelajari oleh siswa, memperbaiki dan meningkatkan kualitas proses pembelajaran yang dilakukan. Peraturan Pemerintah Nomor 19 Tahun 2005 tentang Standar Nasional Pendidikan Pasal 63 Ayat (1) mengamanatkan bahwa penilaian pendidikan pada jenjang pendidikan dasar dan menengah terdiri atas: 1) penilaian hasil belajar oleh pendidik; 2) penilaian hasil belajar oleh satuan pendidikan; dan 3) penilaian hasil belajar oleh pemerintah. Penilaian hasil belajar oleh pemerintah melalui USBN bertujuan untuk menilai pencapaian kompetensi lulusan secara nasional pada matapelajaran tertentu, penentuan kelulusan pada satuan pendidikan tertentu, pemantauan ketercapaian kurikulum, dan sebagai salah satu dasar seleksi untuk masuk pada jenjang pendidikan berikutnya. Selain itu, penilaian hasil belajar juga dapat digunakan sebagai bahan penyusunan laporan kemajuan hasil pembelajaran, dan memperbaiki proses pembelajaran.

Pada akhir jenjang sekolah dasar/madrasah ibtidaiyah, siswa-siswa mengikuti Ujian Sekolah Berstandar Nasional (USBN) sebagai salah satu bentuk evaluasi pembelajaran. Jenis soal yang digunakan dalam evaluasi pembelajaran harus memenuhi kriteria soal yang baik agar soal tersebut mampu mengukur kemampuan siswa yang sebenarnya dan mampu membedakan kemampuan siswa yang tinggi dan rendah. Semakin tinggi kemampuan siswa memahami suatu konsep, semakin tinggi pula peluang menjawab soal dengan benar, dan sebaliknya.

Pada umumnya untuk penilaian USBN digunakan tes tertulis dengan bentuk pilihan ganda (PG) sebagai instrumen penilaian atau prosedur yang baku (terstandar). Penggunaan tes pilihan ganda (PG) dipandang sebagai tes objektif yang efisien digunakan untuk jumlah peserta besar. Soal pilihan ganda mempunyai ciri-ciri terdiri dari pertanyaan atau pernyataan dan pilihan jawaban yang mengandung jawaban benar dan jawaban salah sebagai pengecoh. Soal pilihan ganda yang baik harus memiliki pengecoh yang relatif homogen, sehingga tidak mudah ditebak oleh respons (Sanaky, 1998; Ratnaningsih, 2013: 99). Pengecoh yang baik apabila menyebabkan siswa merasa bingung memilih jawaban yang benar.

Ilmu Pengetahuan Alam (IPA) merupakan salah satu matapelajaran yang diujikan pada USBN di tingkat sekolah dasar/madrasah ibtidaiyah. Penilaian pembelajaran IPA harus diperhatikan dengan serius dan digunakan sebagai cara untuk menilai proses dan hasil belajar, karena dengan adanya penilaian akan menghasilkan informasi penting yang bermanfaat untuk menilai pencapaian sekaligus untuk memperbaiki program pembelajaran. Menyongsong pelaksanaan USBN, sekolah biasanya memprogramkan try out USBN sebagai latihan persiapan USBN bagi siswa. Try out USBN tersebut terlaksana atas kerja sama sekolah dengan berbagai 


\section{MADRASAH}

Jurnal Pendidikan dan Pembelajaran Dasar

p ISSN: 1979-5599 | e ISSN: 2502-194X

Pag e | $\mathbf{3 1}$

lembaga, meliputi Dinas Pendidikan Dasar dan Menengah maupun bimbingan belajar tertentu yang telah ditunjuk oleh dinas pendidikan setempat. Meskipun hanya sebagai latihan, soal-soal try out harus dibuat sebaik mungkin, karena baik buruknya soal akan mempengaruhi perolehan hasil belajar siswa. Hasil try out diharapkan dapat memberikan gambaran tentang kesiapan siswa menghadapi USBN. Oleh karena itu, soal yang akan diujikan sebaiknya dianalisis terlebih dahulu melalui tahap telaah kualitatif dan empiris.

Analisis butir soal secara kualitatif dilakukan untuk menilai item soal ditinjau dari aspek materi, konstruksi dan bahasa (Huda, 2015), sedangkan analisis butir soal secara empiris dilakukan menggunakan pendekatan teori tes klasik dan teori tes modern. Dalam penelitian ini digunakan teori tes klasik/Classical Test Theory (CTT). Ciri dari teori tes klasik diperlihatkan dari kenyataan bahwa kelompok butir tes tidak dapat dipisahkan dari kelompok peserta tes (Sudaryono, 2011:721). Artinya, kelompok peserta tes yang sama harus menjawab kelompok butir tes yang sama. Jika kelompok tes yang sama dijawab kelompok peserta tes yang berbeda, dapat menyebabkan ciri karakteristik kelompok butir tes tersebut akan berubah, sehingga taraf kesukaran dan daya pembeda kelompok butir tes akan berubah. Salah satu keunggulan teori tes klasik terletak pada konsepnya yang mudah dipahami serta penggunaannya dapat dilakukan pada tes berskala kecil (Mistiani, 2016:133). Dari analisis teori tes klasik didapatkan informasi mengenai validitas, reliabilitas, tingkat kesukaran, daya pembeda, dan efektivitas pengecoh/ distraktor. Selanjutnya sebuah tes yang baik itu, harus valid dan reliabel. Validitas merupakan dukungan bukti dan teori terhadap penafsiran skor tes sesuai dengan tujuan penggunaan tes (Azwar, 2013:37). Lebih lanjut Azwar menjelaskan bahwa reliabilitas merupakan koefisien yang menunjukkan tingkat keajegan atau konsistensi hasil pengukuran suatu tes. Konsisten hasil pengukuran tersebut mengacu pada penggunaan alat ukur yang sama untuk orang yang berbeda atau pada waktu yang berbeda tetapi kondisi yang sama.

Dalam penyusunan kisi-kisi soal harus memperhatikan langkah-langkah yang tepat, yaitu 1) penentuan kompetensi dasar (KD) yang akan diukur, 2) pemilihan materi yang esensial, dan 3) perumusan indikator yang mengacu pada KD dengan memperhatikan materi dan level kognitif. Level kognitif merupakan tingkat kemampuan siswa secara individual maupun kelompok yang dapat dijabarkan dalam tiga level kognitif. Level 1 menunjukkan tingkat kemampuan yang rendah yaitu mencakup pengetahuan dan pemahaman (knowing), level 2 menunjukkan tingkat kemampuan yang lebih tinggi yaitu mencakup penerapan (applying), dan level 3 menunjukkan tingkat kemampuan tinggi yaitu mencakup penalaran dan logika (reasoning) (Puspendik, 2017:7-8).

Level kognitif di atas dapat dikaitkan dengan teori pemerolehan konsep yang telah dikemukakan oleh beberapa ahli, yaitu Piaget, J.Bruner, Osborne dan Wittrock (Dahar, 1989). Berdasarkan prinsip konstruktivisme yang dikemukakan oleh Piaget, tiga aspek perkembangan intelektual meliputi struktur kognitif, isi, dan fungsi (Ginsburg \& Opper, 2016). Isi berkaitan dengan apa yang dipikirkan oleh seseorang atau apa yang menjadi perhatian seseorang pada saat tertentu. Seorang anak bisa jadi memiliki cara mengaitkan antara struktur kognitif dengan pengalaman di dunia nyata; seseorang secara aktif membangun struktur kognitif yang baru dengan cara mereorganisasi struktur kognitif yang lama dengan pengalaman kehidupan seharihari. Aktivitas dari struktur kognitif tersebut berkaitan dengan fungsinya. Fungsi merupakan cara yang digunakan seseorang untuk perkembangan intelektual. Piaget membagi perkembangan tingkat kognitif individu menjadi 4 (empat) tahap, yaitu 1) tahap sensorimotor: dari kelahiran -umur 2 tahun (anak-anak mulai menggunakan panca indera), 2) tahap praoperasional: umur 2-7 tahun (kemahiran terhadap kemampuan motorik), 3) tahap operasional konkrit: umur 7-11 tahun (anak mulai berpikir logis mengenai peristiwa nyata), dan 4) tahap operasional formal: umur di atas 11 tahun (perkembangan pemikiran abstrak) (Wahyuni, 2010).

Berdasarkan uraian di atas, butir soal yang telah diujikan pada try out USBN perlu dianalisis agar diperoleh informasi mengenai kualitas soal yang telah disusun oleh tim Kelompok 
Kerja Guru (KKG) kelas VI Kabupaten Tulungagung. Dalam analisis butir soal digunakan teori tes klasik berbantuan program ITEMAN 4.30 yang merupakan versi terbaru. Program ini merupakan bagian dari paket Micro Computer Adaptive Test (MicroCAT) yang dikembangkan oleh Assessment Systems Corporation pada tahun 1982 dan telah mengalami revisi pada tahun 1984, 1986, 1988, 1993 dan 2013; mulai dari versi 2.00 sampai dengan versi 4.30. Tujuan penelitian ini: 1) mengetahui karakteristik butir soal IPA try out USBN Tahun Ajaran 2018/2019 berdasarkan classical test theory (CTT); dan 2) mengetahui berapa jumlah soal IPA try out USBN Tahun Ajaran 2018/2019 dalam kaitannya dengan level kognitif siswa SD/MI. Selanjutnya, dari hasil analisis butir soal dapat diketahui soal-soal yang berkualitas baik, perlu revisi atau ditolak. Soal-soal yang berkualitas baik dapat dimasukkan ke dalam bank soal serta dapat dijadikan sebagai referensi soal pada saat pelaksanaan USBN yang sesungguhnya.

\section{B. METODE PENELITIAN}

Jenis penelitian ini adalah penelitian deskriptif. Penelitian deskriptif merupakan metode penelitian yang berusaha menggambarkan dan menginterpretasikan objek sesuai dengan apa adanya (Sukardi, 2003). Penelitian ini mendeskripsikan atau menggambarkan suatu kejadian yang terjadi secara faktual, sistematis dan akurat. Penelitian ini menggambarkan data kuantitatif yang diperoleh menyangkut keadaan subjek atau respons dari suatu populasi, maka pendekatan yang digunakan adalah pendekatan kuantitatif.

Lokasi penelitian ini di Kabupaten Tulungagung, Jawa Timur yang dilaksanakan pada tanggal 21 Februari 2019. Objek dalam penelitian ini adalah Lembar Jawab Komputer (LJK) sebanyak 5022 siswa yang mengikuti try out USBN SD/MI tahun ajaran 2018/2019 yang dirancang oleh Kelompok Kerja Guru (KKG) Guru Kelas 6 yang dikoordinasi oleh Dinas Pendidikan Dasar Kabupaten Tulungagung. Selanjutnya dalam proses pelaksanaannya, Dinas Pendidikan Dasar Kabupaten Tulungagung berkerjasama dengan tim Radar Tulungagung dalam mencetak dan mendistribusikannya, sementara untuk proses scanner LJK berkerjasama dengan tim Primagama Tulungagung. Lembar jawab komputer tersebut dianalisis untuk mengetahui karakteristik butir soal. Dalam kaitannya dengan level kognitif yang mengacu pada kisi-kisi USBN SD/MI tahun ajaran 2018/2019 dilakukan Focus Group Discussion (FGD) oleh 4 dosen (2 dosen Evaluasi Pembelajaran dan 1 dosen PGMI UIN Maulana Malik Ibrahim Malang, serta 1 dosen Tadris Kimia IAIN Tulungagung).

Teknik pengumpulan data dalam penelitian ini adalah dengan menggunakan dokumentasi. Peneliti langsung mendatangi tim Primagama Tulungagung untuk meminta izin agar dapat mengambil data respons LJK perserta try out USBN SD/MI tahun ajaran 2018/2019. Jumlah soal try out IPA USBN SD/MI tahun ajaran 2018/2019 yang dianalisis berjumlah 35 butir. Analisis karakteristik butir soal berdasarkan Classical Test Theory (CTT). Analisis tersebut dilakukan untuk mengetahui informasi tentang butir/ perangkat soal yang layak dan tidak layak untuk dipakai kemudian hari berdasarkan parameter butir/ perangkat soal, yaitu validitas, reliabilitas, tingkat kesukaran, daya pembeda, dan efektivitas pengecoh.

Analisis validitas butir soal IPA try out USBN SD/MI tahun ajaran 2018/2019 menggunakan program komputer Statistical Package For The Social Sciences (SPSS versi 16). Jika koefisien korelasi skor butir dengan skor total lebih besar dari koefisien korelasi tabel-r, koefisien butir signifikan dan butir tersebut valid secara empiris (Matondang, 2009:92). Artinya nilai $r$ hitung $>\mathrm{r}$ tabel $(\mathrm{N}=5022, \mathrm{a}=0,05$ maka nilai $\mathrm{r}$ tabel $=0,0232)$.

Analisis reliabilitas perangkat soal IPA try out USBN SD/MI tahun ajaran 2018/2019 dengan menggunakan program komputer Iteman versi 4.3. Reliabilitas perangkat soal dapat dilihat pada kolom Alpha (KR-20) dengan kriteria yang tercantum pada Tabel B.1.

Tabel B.1 Kriteria Reliabilitas

\begin{tabular}{cc}
\hline Kriteria & Keterangan \\
\hline $0,80<\mathrm{r} \leq 1,00$ & Sangat Tinggi \\
\hline
\end{tabular}

Vol. 12 No. 1 Desember 2019

Madrasah homepage: http://ejournal.uin-malang.ac.id/index.php/madrasah/index 


\section{MADRASAH}

Jurnal Pendidikan dan Pembelajaran Dasar

p ISSN: 1979-5599 | e ISSN: 2502-194X

Page

\begin{tabular}{cc}
\hline Kriteria & Keterangan \\
\hline $0,60<\mathrm{r} \leq 0,80$ & Tinggi \\
\hline $0,40<\mathrm{r} \leq 0,60$ & Sedang \\
\hline $0,20<\mathrm{r} \leq 0,40$ & Rendah \\
\hline $\mathrm{r} \leq 0,20$ & Sangat Rendah \\
\hline
\end{tabular}

Sumber: (Setyawarno, 2017:15)

Analisis tingkat kesukaran butir perangkat soal IPA try out USBN SD/MI tahun ajaran 2018/2019 dengan menggunakan program komputer Iteman versi 4.3. Tingkat kesukaran butir dapat dilihat pada kolom $P$ dengan kriteria yang tercantum pada Tabel B.2.

Tabel B.2 Kriteria Tingkat Kesukaran

\begin{tabular}{cc}
\hline Kriteria & Keterangan \\
\hline $0,81-1,00$ & Sangat Mudah \\
\hline $0,61-0,80$ & Mudah \\
\hline $0,41-0,60$ & Sedang \\
\hline $0,21-0,40$ & Sukar \\
\hline $0,00-0,20$ & Sangat Sukar \\
\hline
\end{tabular}

Sumber: (Setyawarno, 2017:23)

Analisis daya pembeda butir perangkat soal IPA try out USBN SD/MI tahun ajaran 2018/2019 dengan menggunakan program komputer Iteman versi 4.3. Daya pembeda butir dapat dilihat pada kolom Rpbis dengan kriteria yang tercantum pada Tabel B.3.

Tabel B.3 Kriteria Daya Pembeda

\begin{tabular}{cc}
\hline Kriteria & Keterangan \\
\hline $0,40-1,00$ & Baik (tanpa revisi) \\
\hline $0,30-0,39$ & Sedang (tidak perlu direvisi) \\
\hline $0,20-0,29$ & Cukup Baik (perlu direvisi) \\
\hline Negatif $-0,19$ & Buruk \\
\hline
\end{tabular}

Sumber: (Azwar, 2012:140)

Informasi efektivitas pengecoh juga dapat diperoleh pada program komputer Iteman versi 4.3 yaitu pada kolom Prop. (Mardapi, 2008:143) Pengecoh dikatakan berfungsi apabila nilai dari Prop pada setiap pilihan ganda memiliki nilai yang lebih besar dari nilai 0,05 . Nilai proporsi dari opsi setiap butir soal yang memiliki nilai kurang dari nilai Prop, maka distraktor tersebut perlu direvisi.

Analisis butir soal yang baik berdasarkan Classical Test Theory (CTT) apabila mempunyai tingkat kesukaran 0,31 sampai 0,70 (sedang), daya beda minimal 0,30 (sedang); dan pengecoh untuk tiap respons minimal 2\% (Huda, 2015). Penentuan kriteria butir soal yang baik dalam penelitian dengan mengadopsinya menjadi kriteria yang lebih detail seperti ditunjukkan pada Tabel B.4.

Tabel B.4 Kriteria Karakteristik Butir Soal

\begin{tabular}{llllll} 
Validitas & Reliabilitas & $\begin{array}{l}\text { Tingkat } \\
\text { Kesukaran }\end{array}$ & $\begin{array}{l}\text { Daya } \\
\text { Pembeda }\end{array}$ & $\begin{array}{l}\text { Efektivitas } \\
\text { Pengecoh }\end{array}$ & Keterangan \\
\hline Valid & $\begin{array}{l}\text { Minimal } \\
\text { Tinggi }\end{array}$ & Sedang & Sedang & Tanpa revisi & Baik \\
\hline
\end{tabular}




\begin{tabular}{llll} 
Valid & $\begin{array}{l}\text { Minimal } \\
\text { Tinggi }\end{array}$ & Jika ada satu kriteria soal baik tidak terpenuhi & Cukup baik \\
\hline Valid & $\begin{array}{l}\text { Minimal } \\
\text { Tinggi }\end{array}$ & Jika ada dua kriteria soal baik tidak terpenuhi & $\begin{array}{l}\text { Kurang } \\
\text { baik }\end{array}$ \\
\hline Valid & $\begin{array}{l}\text { Minimal } \\
\text { Tinggi }\end{array}$ & Jika ketiga kriteria soal baik tidak terpenuhi & Tidak baik \\
& & \\
\hline
\end{tabular}

Analisis butir dalam kaitannya level kognitif dapat diperoleh dengan focus group discussion (FGD) 4 dosen. Level kognitif yang digunakan sesuai panduan penulisan soal SD/MI Puspendik tahun 2017. Pada proses awal dosen diberikan pubrik ceklist untuk menilai dan mengelompokkan sesuai dengan level kognitif dari 35 butir soal IPA try out USBN SD/MI tahun ajaran 2018/2019. Selanjutnya direkap, dan hasil keputusan setiap butir soal masuk level kognitif berdasarkan modus ( 3 atau 4 dosen dengan penilaian yang sama), ketika tidak ada keputusan baru proses telaah dan diskusi.

\section{HASIL DAN PEMBAHASAN}

1. Analisis Karakteristik Butir Soal

Analisis karakteristik butir soal berdasarkan Classical Test Theory (CTT) dilakukan dengan menggunakan bantuan program komputer SPSS versi 16 dan Iteman versi 4.3. Analisis tersebut menghasilkan informasi tentang butir/ perangkat soal yang layak dan tidak layak untuk dipakai kemudian hari berdasarkan parameter butir/ perangkat soal, yaitu validitas, reliabilitas, tingkat kesukaran, daya pembeda, dan efektivitas pengecoh.

Analisis validitas dengan program komputer SPSS versi 16 nilai $\mathrm{r}$ hitung yang diperoleh terletak pada interval 0,185 - 0,521 >0,0232 sehingga dari 35 butir soal dinyatakan valid. Analisis reliabilitas dengan program komputer Iteman versi 4.3 pada kolom Alpha (KR-20) nilai 0,818 termasuk (sangat tinggi). Analisis tingkat kesukaran butir soal dengan program komputer Iteman versi 4.3 dapat dilihat pada kolom $P$ yang direkap pada Tabel C.1.

Tabel C.1 Rekap tingkat kesukaran butir soal IPA try out USBN TA 2018/2019

\begin{tabular}{ccc}
\hline Kriteria & Jumlah & Persentase \\
\hline Sukar & 4 & 11,43 \\
\hline Sedang & 9 & 25,71 \\
\hline Mudah & 16 & 45,71 \\
\hline Sangat Mudah & 6 & 17,14 \\
\hline & 35 & 100,00
\end{tabular}

Berdasarkan Tabel C.1 bahwa sebaran tingkat kesukaran merata, karena setiap kriteria terwakili. Soal dengan kriteria sukar yaitu no 76, 85, 89, dan 104. Soal dengan kriteria sedang yaitu no $71,72,79,80,82,88,92,96$, dam 102 . Soal dengan kriteria mudah yaitu no $73,74,75,78$, $84,86,87,90,91,93,94,95,100,101,103$, dan 105 . Soal dengan kriteria sangat mudah yaitu no 77 , 81, 83, 97, 98, dan 99 .

Analisis daya pembeda butir soal dengan program komputer Iteman versi 4.3 dapat dilihat pada kolom Rpbis yang direkap pada Tabel C.2.

Tabel C.2 Rekap daya pembeda butir soal IPA try out USBN TA 2018/2019

\begin{tabular}{ccc}
\hline Kriteria & Jumlah & Persentase \\
\hline Buruk & 3 & 8,57 \\
\hline Cukup Baik & 12 & 34,29 \\
\hline Sedang & 15 & 42,86
\end{tabular}




\section{MADRASAH}

Jurnal Pendidikan dan Pembelajaran Dasar

p ISSN: 1979-5599 | e ISSN: 2502-194X

Pag e

\begin{tabular}{ccc}
\hline Kriteria & Jumlah & Persentase \\
\hline Baik & 5 & 14,29 \\
\hline & 35 & 100,00 \\
\hline
\end{tabular}

Berdasarkan Tabel C.2 bahwa lebih dari 50\% butir soal IPA try out USBN tahun ajaran 2018/2019 mampu membedakan siswa yang memiliki kemampuan tinggi dengan rendah. Soal yang memiliki daya pembeda buruk yaitu nomor 85,86 , dan 87 . Soal dengan kriteria cukup baik yaitu nomor $71,75,76,79,80,81,88,89,91,97,98$, dan 104. Soal dengan kriteria sedang yaitu nomor $72,73,74,75,77,78,83,84,87,93,99,100,101,102,103$, dan 105 . Soal dengan kriteria sangat mudah yaitu nomor 82, 90, 92, 94, dan 95 .

Informasi efektivitas pengecoh juga dapat diperoleh pada program komputer Iteman versi 4.3 dapat dilihat pada kolom Prop pada Tabel C.3.

Tabel C.3 Rekap efektivitas pengecoh opsi jawaban soal IPA try out USBN TA 2018/2019

\begin{tabular}{lcc}
\hline \multicolumn{1}{c}{ Keputusan } & Jumlah & Persentase \\
\hline tanpa revisi & 17 & 48,57 \\
\hline revisi salah 1 opsi & 9 & 25,71 \\
\hline revisi salah 2 opsi & 5 & 14,29 \\
\hline revisi salah 3 opsi & 4 & 11,43 \\
\hline & 35 & 100,00 \\
\hline
\end{tabular}

Berdasarkan tabel C.3 bahwa 48,57\% opsi jawaban butir soal IPA try out USBN tahun ajaran 2018/2019 efektivitas mengecoh para peserta try out. Soal yang memiliki opsi jawaban tanpa revisi yaitu nomor 72, 73, 76, 79, 82, 85, 87, 88, 89, 92, 96, 100, 101, 102, 103, 104, dan 105. Soal yang perlu direvisi salah 1 opsi jawaban yaitu nomor 71, 75, 78, 80, 84, 90, 91, 94, dan 95. Soal yang perlu direvisi salah 2 opsi jawaban yaitu nomor 74, 86, 93, 97, dan 99. Soal yang perlu direvisi salah 3 opsi jawaban yaitu nomor 77, 81, 83, dan 98 .

Berdasarkan karakteristik butir (validitas, reliabelitas, tingkat kesukaran, daya pembeda, dan efektivitas pengecoh) soal IPA try out USBN tahun ajaran 2018/2019 dapat dikategorikan pada Tabel C.4.

Tabel C.4 Rekap karakteritik butir soal IPA try out USBN TA 2018/2019

\begin{tabular}{ccc}
\hline Kesimpulan & Jumlah & Persentase \\
\hline baik & 2 & 5,71 \\
\hline cukup baik & 11 & 31,43 \\
\hline kurang baik & 13 & 37,14 \\
\hline tidak baik & 9 & 25,71 \\
\hline & 35 & 100 \\
\hline
\end{tabular}

Berdasarkan Tabel C.4 bahwa 13 butir (37,14\%) soal IPA try out USBN tahun ajaran 2018/2019 memiliki karakteristik cukup baik dan baik, sehingga dapat dimasukkan dalam bank soal. Soal memiliki karakteristik baik yaitu nomor 72 dan 102. Soal memiliki karakteristik cukup baik yaitu nomor $73,79,82,87,88,92,96,100,101,103$, dan 105 . Soal memiliki karakteristik kurang baik yaitu nomor 71, 74, 76, 77, 78, 80, 83, 84, 85, 89, 93, 99, dan 104. Soal memiliki karakteristik tidak baik yaitu nomor 75, 81, 86, 90, 91, 94, 95, 97, dan 98.

Pada analisis karakteristik butir soal IPA try out USBN tahun ajaran 2018/2019 terdapat 4 kategori berikut:

1. Kategori butir soal baik tenyata setelah ditelaah contohnya: 
No. 72 dengan tingkat kesukaran (sedang), daya pembeda (sedang), dan efektivitas pengecoh semua berfungsi dengan level kognitif L1 (pengetahuan)

Lahan pertanian yang berada di lereng pegunungan dibuat sengkedan dengan tujuan...
a. Mencegah terjadinya abrasi
b. Mencegah terjadinya gempa
c. Mencegah terjadinya erosi*
d. mencegah terjadinya banjir

2. Kategori butir soal cukup baik setelah ditelaah contohnya:

No. 92 dengan tingkat kesukaran (sedang), daya pembeda (baik), dan efektivitas pengecoh semua berfungsi dengan level kognitif L2 (aplikasi)

Perubahan wujud zat dari padat menjadi cair biasa dimanfaatkan dal kehidupan sehari-hari yaitu...
a. Pemanasan air
b. Peleburan logam*
c. Pembuatan es kering
d. Penggunaan kapur barus

3. Kategori kurang baik setelah ditelaah contohnya:

No. 76 dengan tingkat kesukaran (sukar), daya pembeda (cukup baik), dan efektivitas pengecoh semua berfungsi dengan level kognitif L3 (penalaran)

Petani dalam menggunakan pupuk pestisida kadang tidak sesuai takaran yang diberikan, sehingga penggunaan pestisida secara berlebihan dapat berdampak pada ...
a. Meledaknya populasi gulma dengan cepat*
b. Kuranganya suplai air di lahan pertanian
c. Lahan petanian menjadi kering
d. Tanaman gulma mati

4. Kategori tidak baik setelah ditelaah contohnya:

No. 81 dengan tingkat kesukaran (sangat mudah), daya pembeda (cukup baik), dan efektivitas pengecoh tidak berfungsi dengan level kognitif L3 (penalaran)

Yuda sekarang sudah tampak berkumis, dadanya lebih bidang, dan suaranya membesar. Munculnya ciri seperti itu menandakan yuda telah memasuki ...
a. Masa anak-anak
b. Masa remaja*
c. Masa penuaan
d. Masa lansia

\section{Analisis Level Kognitif}

Analisis butir soal try out IPA USBN tahun ajaran 2018/2019 dalam kaitannya dengan level kognitif yang digunakan sesuai panduan penulisan soal 2017 SD/MI dapat dikategorikan sesuai Tabel C.5.

Tabel C.5 Rekap level kognitif butir soal IPA try out USBN 2018/2019

\begin{tabular}{ccc}
\hline Kesimpulan & Jumlah & Persentase \\
\hline L1 (pengetahuan) & 11 & 31,43 \\
\hline L1 (pemahaman) & 10 & 28,57 \\
\hline L2 (aplikasi) & 4 & 11,43 \\
\hline L3 (penalaran) & 10 & 28,57 \\
\hline & 35 & 100 \\
\hline
\end{tabular}

Berdasarkan Tabel C.5 bahwa butir soal IPA try out USBN tahun ajaran 2018/2019 Kabupaten Tulungagung mencakup semua level kognitif. Soal dengan level kognitif L1 


\section{MADRASAH}

Jurnal Pendidikan dan Pembelajaran Dasar

p ISSN: 1979-5599 | e ISSN: 2502-194X

P a g e | 37

(pengetahuan) yaitu no 72, 75, 79, 80, 88, 91, 93, 95, 97, 102, dan 103. Soal dengan level kognitif L1 (pemahaman) yaitu no 71, 73, 77, 78, 82, 84, 86, 90, 100, dan 105. Soal dengan level kognitif L2 (aplikasi) yaitu no 74, 87, 92, dan 96. Soal dengan level kognitif L3 (penalaran) yaitu no 76, 81, 83, $85,89,94,98,99,101$, dan 104. Beberapa soal yang menjadi bahan diskusi diantaranya:

No. 71 Alur rantai makanan yang benar terdapat pada...

a. Lumut $\rightarrow$ ikan mujair $\rightarrow$ ikan bawal $\rightarrow$ pengurai*

b. Lumut $\rightarrow$ ikan bawal $\rightarrow$ ikan mujair $\rightarrow$ pengurai

c. Ikan bawal $\rightarrow$ ikan mujair $\rightarrow$ lumut $\rightarrow$ pengurai

d. Ikan mujair $\rightarrow$ ikan bawal $\rightarrow$ lumut $\rightarrow$ pengurai

dari hasil ceklist sementara 2 dosen memilih level 1a (pengetahuan) dan 2 dosen memilih level $1 \mathrm{~b}$ (pemahaman), sedangkan analisis lebih lanjut ke-4 dosen sepakat masuk level $1 \mathrm{~b}$ (pemahaman) dikarenakan siswa harus memahami rantai makan dan kemudian memilih rantai makan pada ekosistem kolam air tawar. Kuncinya adalah A dengan pembahasan lumut (produsen) $\rightarrow$ ikan mujair (konsumen I) $\rightarrow$ ikan bawal (konsumen II) $\rightarrow$ pengurai (Dekomposer).

No. 77 Bentuk hubungan saling ketergantungan lebah dan tumbuhan bunga yang saling menguntungkan adalah lebah membantu pernyerbukan bunga, sedangkan bunga menyediakan...
a. Daun bagi lebah
b. Nektar bagi lebah*
c. Biji bagi lebah
d. Akar bagi lebah

dari hasil ceklist sementara 1 dosen memilih level 1a (pengetahuan), 2 dosen memilih level $1 b$ (pemahaman) dan 1 dosen memilih level 3 (analisis), sedangkan analisis lebih lanjut ke-4 dosen sepakat masuk level $1 \mathrm{~b}$ (pemahaman) dikarenakan siswa harus memahami simbiosis mutualisme (kedua saling menguntungkan) dan kemudian diberikan contoh hubungan lebah dengan bunga. Kuncinya adalah B dengan pembahasan lebah juga menghisap madu dan nektar dari kelopak bunga yang membantu proses penyerbukan bunga tersebut.

No. 95 apabila dua kutub magnet yang senama yang didekatkan akan terjadi...
a. Tarik menarik
a. Sabit
b. Cembung
c. Separuh
d. Purnama

b. Saling melekat

c. Tolak menolak*

d. Saling berdekatan

dari hasil ceklist sementara 2 dosen memilih level 1a (pengetahuan), dan 2 dosen memilih level $1 \mathrm{~b}$ (pemahaman), sedangkan analisis lebih lanjut ke-4 dosen sepakat masuk level 1a (pengetahuan) dikarenakan siswa hanya mengetahui sifat-sifat dari magnet.

No. 103 gerhana bulan akan terjadi pada fase bulan...

dari hasil ceklist sementara 2 dosen memilih level 1a (pengetahuan), dan 2 dosen memilih level $1 \mathrm{~b}$ (pemahaman), sedangkan analisis lebih lanjut ke-4 dosen sepakat masuk level 1a (pengetahuan) dikarenakan siswa hanya mengetahui macam-macam fase bulan.

Dalam kaitannya butir soal yang masuk dalam bank soal dengan level kognitif pada digambarkan pada Tabel C.6.

Tabel C.6 Rekap kaitannya butir soal yang masuk dalam bank soal dengan level kognitif soal IPA try out USBN 2018/2019

\begin{tabular}{ccc}
\hline Kesimpulan & Jumlah & Persentase \\
\hline L1 (pengetahuan) & 5 & 38,46 \\
\hline
\end{tabular}




\begin{tabular}{lcc}
\hline \multicolumn{1}{c}{ Kesimpulan } & Jumlah & Persentase \\
\hline L1 (pemahaman) & 4 & 30,77 \\
\hline L2 (aplikasi) & 3 & 23,08 \\
\hline L3 (penalaran) & 1 & 7,69 \\
\hline & 13 & 100 \\
\hline
\end{tabular}

Berdasarkan Tabel C.6 dalam kaitannya butir soal yang masuk dalam bank soal dengan level kognitif butir soal IPA try out USBN tahun ajaran 2018/2019 Kabupaten Tulungagung masih didominasi pada level kognitif L1 (pengetahuan dan pemahaman). (Mukhlisah, 2015:127-128) Hal ini sesuai dengan karakteristik perkembangan kognitif pada siswa Sekolah Dasar menurut teori Piaget pada tahap operasi berpikir kongkrit rentang usia 7-11 tahun. Jika dihubungkan dengan kemampuan yang dapat didemonstrasikan berdasarkan level kognitif, maka aspek pengetahuan, pemahaman, dan aplikasi sudah dapat diterapkan.

\section{KESIMPULAN}

Berdasarkan hasil penelitian dan pembahasan pada butir soal IPA try out USBN tahun ajaran 2018/2019 Kabupaten Tulungagung dapat disimpulkan sebagai berikut:

1. Karakteristik butir soal IPA try out USBN Tahun Ajaran 2018/2019 berdasarkan Classical Test Theory (CTT) dalam aspek: a) validitas 35 butir soal valid; b) reliabilitas nilainya 0,818 termasuk sangat tinggi; c) tingkat kesukaran: 4 butir (11,43\%) sukar, 9 butir $(25,71 \%)$ sedang, 16 butir $(45,71 \%)$ mudah dan 6 butir $(7,14 \%)$ sangat mudah; d) daya pembeda: 3 butir $(8,57 \%)$ buruk, 12 butir (34,29\%) cukup baik, 15 butir (42,86\%) sedang, dan 5 butir (14,29\%) baik; e) efektifitas pengecoh: 17 butir (48,57\%) tanpa revisi, 9 butir $(25,71 \%)$ revisi salah 1 opsi, 5 butir $(14,29 \%)$ revisi salah 2 opsi, dan 4 butir $(11,43 \%)$ revisi salah 3 opsi; 6$) 13$ butir $(37,14 \%)$ soal IPA try out USBN tahun ajaran 2018/2019 memiliki karakteristik cukup baik dan baik, sehingga dapat dimasukkan dalam bank soal.

2. Soal IPA try out USBN tahun ajaran 2018/2019 dalam kaitannya dengan level kognitif, 11 butir soal $(31,43 \%)$ kategori L1 (pengetahuan), 10 butir soal $(28,57 \%)$ kategori L1 (pemahaman), 4 butir soal (11,43\%) kategori L2 (aplikasi), dan 10 butir soal (28,57\%) kategori L3 (penalaran). Dari 13 butir soal yang masuk dalam bank soal dengan level kognitif butir soal IPA try out USBN tahun ajaran 2018/2019 didominasi pada level kognitif L1 (pengetahuan dan pemahaman).

\section{REFERENSI}

Azwar, Saifuddin. (2013). Tes Prestasi (fungsi dan pengembangan pengukuran prestasi belajar) edisi II, Yogyakarta: Pustaka Pelajar Offset.

Dahar, R.W. (1989). Teori-Teori Belajar. Jakarta: Depdikbud Dirjen Dikti.

Dewi Juliah Ratnaningsih. (2013). Analisis Butir Tes Objektif UAS Mahasiswa UT Berdasarkan Teori Tes Modern. Jurnal Pendidikan Terbuka dan Jarak Jauh, Volume 14, Nomor 2, 98-109.

Ginsburg, H.P., \& Opper, S. 2016. Piaget's Theory of Intellectual Development Third Edition. USA: International Psychotherapy Institute.

Huda, Nuril. (2015). Analisis karakteristik perangkat sola ujian akhir semester gasal matematika wajib kelas X di SMA Negeri 9 Yogyakarta. Prosiding Seminar Nasional Matematika dan Pendidikan Matematika di Universitas Muhammadiyah Purworejo. Purworejo: UMP.

Mantondang, Zulkifli. (2009). Validitas dan reliabilitas suatu instrument penelitian. Jurnal Tabularasa PPS UNIMED Vol.6 No. 1. Medan: Unimed.

Mardapi, Djemari. (2008). Teknik Penyusunan Instrumen Tes dan Nontes. Yogyakarta: Mitra Cendikian Press. 


\section{MADRASAH}

Jurnal Pendidikan dan Pembelajaran Dasar

p ISSN: 1979-5599 | e ISSN: 2502-194X

P a g e | 39

Mardapi, Djemari. (2012). Pengukuran Penilaian dan Evaluasi Pendidikan. Yogyakarta: Nuha Medika.

Mistiani, Wiwin. (2016). Analisis butir soal dengan pendekatan classical test theory dan item response theory. Paedagogia: jurnal pendidikan Vol. 5 No. 1: 122-145.

Mukhlisah AM. (2015). Pengembangan kognitif jean Piaget dan peningkatan belajar anak diskalkulia. Jurnal Kependidikan Islam Volume 6 nomor 2. Surabaya: UIN Sunan Ampel.

Peraturan Pemerintah Nomor 19 Tahun 2005 tentang Standar Nasional Pendidikan. Diakses pada tanggal 6 September 2019, hlm 19 https:/ / kemenag.go.id/file/dokumen/PP1905.pdf

Pusat Penilaian Pendidikan Badan Penelitain dan Pengembangan. (2017). Panduan Penulisan Soal 2017 SD/MI. Jakarta: Kemendikbud.

Sanaky. (1998). Teknik Menyusun Alat Evaluasi Belajar Mata Pelajaran Al-Islam dan Bahasa Arab. Makalah disajikan pada acara pembinaan guru Madrasah Mu'allimat Muhammadiyah tanggal 26 September 1998 di Yogyakarta.

Setyawarno, Didik. (2017). Penggunaan Aplikasi Software Iteman (Item and Test Analysis) Untuk Analisis Butir Soal Pilihan Ganda Berdasarkan Teori Tes Klasik. JIFP (Jurnal Ilmu Fisika dan Pembelajarannya) volume 1, no. 1, Palembang: UIN Raden Fatah March 17.

Setyawarno, Didik. (2017). "Modul kuliah penilaian dan evaluasi pembelajaran IPA". Disampaikan pada perkuliahan prodi pendidikan IPA Fakultas MIPA UNY. Yogyakarta: UNY.

Sudaryono. (2011). Implementasi Teori Responsi Butir (Item Response Theory) Pada Penilaian Hasil Belajar Akhir di Sekolah. Jurnal Pendidikan dan Kebudayaan, Vol. 17, Nomor 6, 719-732.

Sukardi. (2003). Metodologi Penelitian Pendidikan: Kompetensi dan Praktinya. Jakarta: Bumi Aksara.

Wahyuni, Tutik Sri. (2010). Kajian Pemahaman Konsep Materi dan Perubahannya pada Siswa Kelas IX SMP Negeri 1 Tulungagung. Skripsi Tidak Diterbitkan. Malang: Jurusan Pendidikan Kimia FMIPA Universitas Negeri Malang. 